\title{
Beit Alpha Cucumber: A New Greenhouse Crop for Florida 1
}

\section{Nicole L. Shaw and Daniel J. Cantliffe ${ }^{2}$}

Dutch type cucumbers (Cucumis sativus), also called European or English cucumbers, are the long, thin-skinned, seedless cucumbers available in most grocery stores. These cucumbers are one of the major greenhouse crops grown in Florida.

Beit Alpha cucumbers are similar in appearance and production to Dutch cucumbers, and trials indicate that Beit Alpha cucumbers can be produced in Florida just as successfully as Dutch cucumbers.

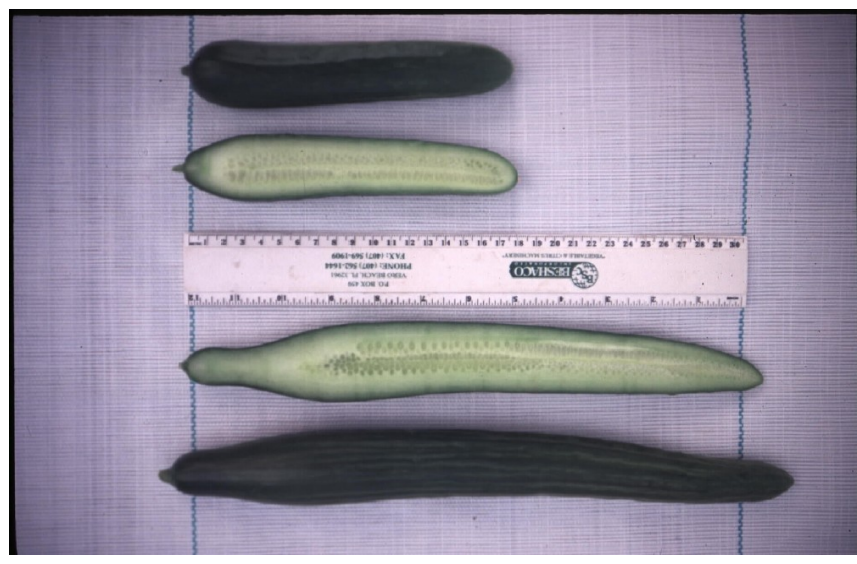

Figure 1. Comparison of Beit Alpha (top) and Dutch-type (bottom) Cucumber Fruit. Credits: Nicole L. Shaw, UF/IFAS
Like Dutch cucumbers, Beit Alpha cucumbers are gynoecious (producing only female flowers) and parthenocarpic, so they require no pollination. The fruit are shorter than Dutch cucumbers, but seedless, smooth, and thin-skinned. Beit Alpha cucumbers are also less susceptible to damage after harvest than the Dutch-type cucumber (Figure 1). In addition, fruit yields of Beit Alpha cucumbers can be up to three times higher than those of Dutch cucumbers. (See Table 2.)

\section{Production Methods}

Beit Alpha cucumbers can be produced in any greenhouse suitable for production of Dutch type cucumbers. For best production of either type of cucumber, the greenhouse should have high enough sidewalls to allow good air movement around the plants. Depending on the region, the greenhouse may need both cooling and heating. Dutch cucumbers prefer a temperature range of $65-90^{\circ} \mathrm{F}$ while Beit Alpha cucumbers are more tolerant of both low and high temperatures $\left(50-100^{\circ} \mathrm{F}\right)$.

1. This document is HS-810, one of a series of the Horticultural Sciences Department, Florida Cooperative Extension Service, Institute of Food and Agricultural Sciences, University of Florida. Original publication date, July 2001. This publication's original authors included Elizabeth M. Lamb, formerly an assistant professor, Horticultural Sciences Department, University of Florida, Indian River Research and Education Center, Fort Pierce, FL. This publication was revised May 2009. Visit the EDIS Web site at http://edis.ifas.ufl.edu.

2. Nicole L. Shaw, senior biological scientist, and Daniel J. Cantliffe, distinguished professor and chairman, Horticultural Sciences Department, Institute of Food and Agricultural Sciences, University of Florida, Gainesville, FL.

The Institute of Food and Agricultural Sciences (IFAS) is an Equal Opportunity Institution authorized to provide research, educational information and other services only to individuals and institutions that function with non-discrimination with respect to race, creed, color, religion, age, disability, sex, sexual orientation, marital status, national origin, political opinions or affiliations. U.S. Department of Agriculture, Cooperative Extension Service, University of Florida, IFAS, Florida A. \& M. University Cooperative Extension Program, and Boards of County Commissioners Cooperating. Millie Ferrer, Interim Dean 


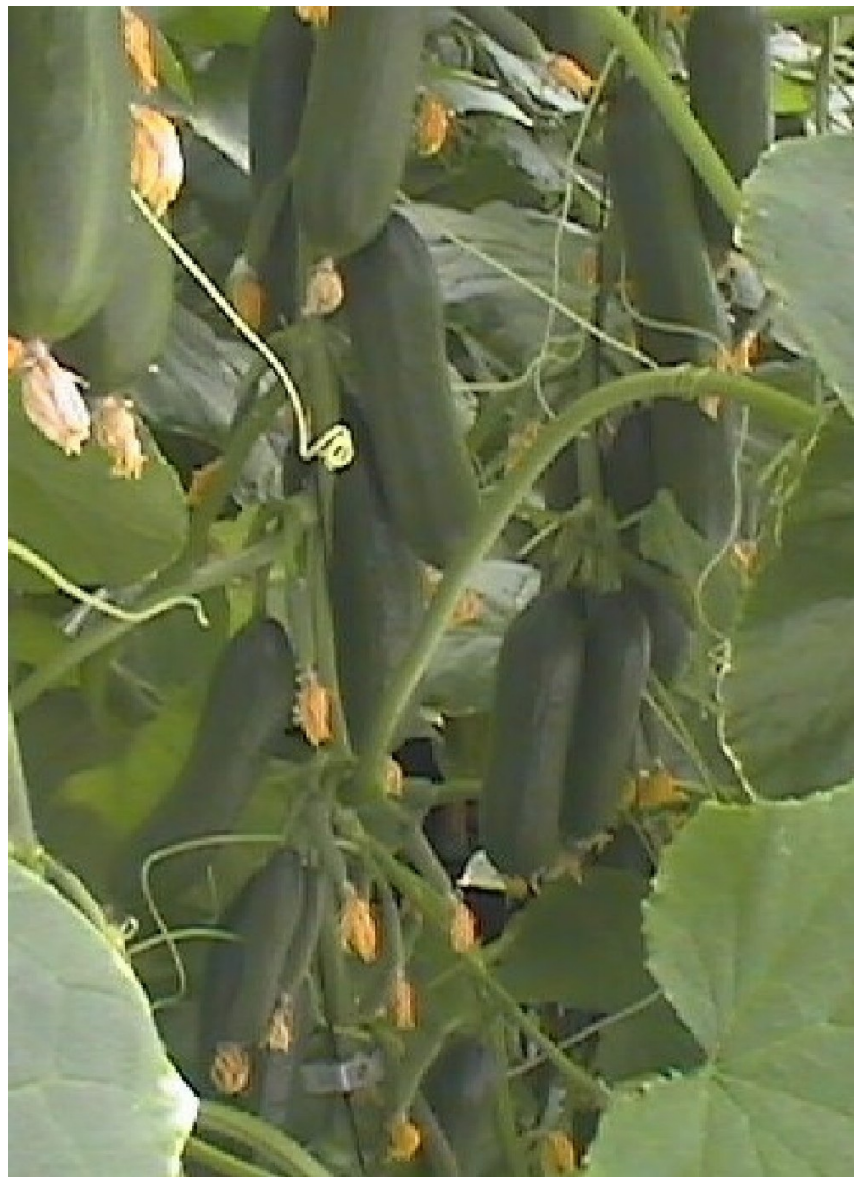

Figure 2. Crop Load on Beit Alpha Cucumber (Cultivar, Sarig). Credits: Daniel J. Cantliffe, UF/IFAS

Both types of cucumbers can be produced in perlite, organic media -- such as pine bark or coconut coir -- or in mixes of organic media and perlite. Although current practice is to use white polyethylene bags filled with media, these cucumbers can be produced in pots or buckets, as well as in bags.

Irrigation is based on achieving a recommended rate of leachate (water loss from the container), approximately 10 - 20 percent of added water, depending on the amount of sunlight and stage of plant growth. Water is piped along the rows in plastic pipe with an emitter placed at each plant. While black pipe is most common, in regions where heating of the water can cause root damage white pipe with a black interior can be used to reduce water temperature algal growth.

The plants should be fertilized at each irrigation with a complete nutrient solution. IFAS recommendations for fertilization of greenhouse cucumbers are provided in Table 1. For more information, see EDIS Bulletin 327, Design Suggestions and Greenhouse Management for Vegetable Production in Perlite and Rockwool Media in Florida, (G. Hochmuth and R. Hochmuth, 1998), http://edis.ifas.ufl.edu/document_cv195, and Florida Greenhouse Vegetable Production Handbook, Volume 3, (G. Hochmuth and R. Hochmuth), http://edis.ifas.ufl.edu/ topic_book_florida_greenhouse_v3.

The $\mathrm{pH}$ of the nutrient solution should be maintained at 5.5 - 6.5. Because electrical conductivity (EC) can vary with water quality and source of fertilizer, EC should not be used as a method of determining correct fertility of the nutrient solution. However, EC can be used as a quick check on the total soluble salts in the nutrient solution. EC should be maintained between $1.5-2.5$ deciSiemens/meter $(1$ deciSiemen/meter $=$ $1 \mathrm{millimhos} /$ centimeter $=640$ parts per million). An emitter can be placed in a plastic jug to collect a sample to test the EC and $\mathrm{pH}$ of the solution.

Plants are individually trellised on twine hung from a horizontal support. Plastic clips are used to attach the vines to the twine at the base of the plant and along the vine as the weight of the fruit load requires. Dutch cucumbers are usually pruned to a single stem with no lateral branches (suckers). Fruit are removed up to the sixth to the eighth node, and the plant is then allowed to set one fruit per node every other node up to the horizontal support. At the top of the support wire, two laterals are trained over the wires. However, Beit Alpha cucumbers set multiple fruits at each node and on the lateral branches, so both the fruit and lateral branches are left on the plant after the eighth node. To avoid excessive vegetative growth, lateral branches can be pruned at the second node on the lateral (Figure 3).

Disease and insect control should be applied as needed in a timely fashion following recommended practices. Insect exclusion with screening will reduce insect-feeding damage and vectoring of diseases. Biological methods of control are available and effective for some of the insects and diseases affecting greenhouse cucumbers. Sanitation by removing pruning debris and damaged fruit can 


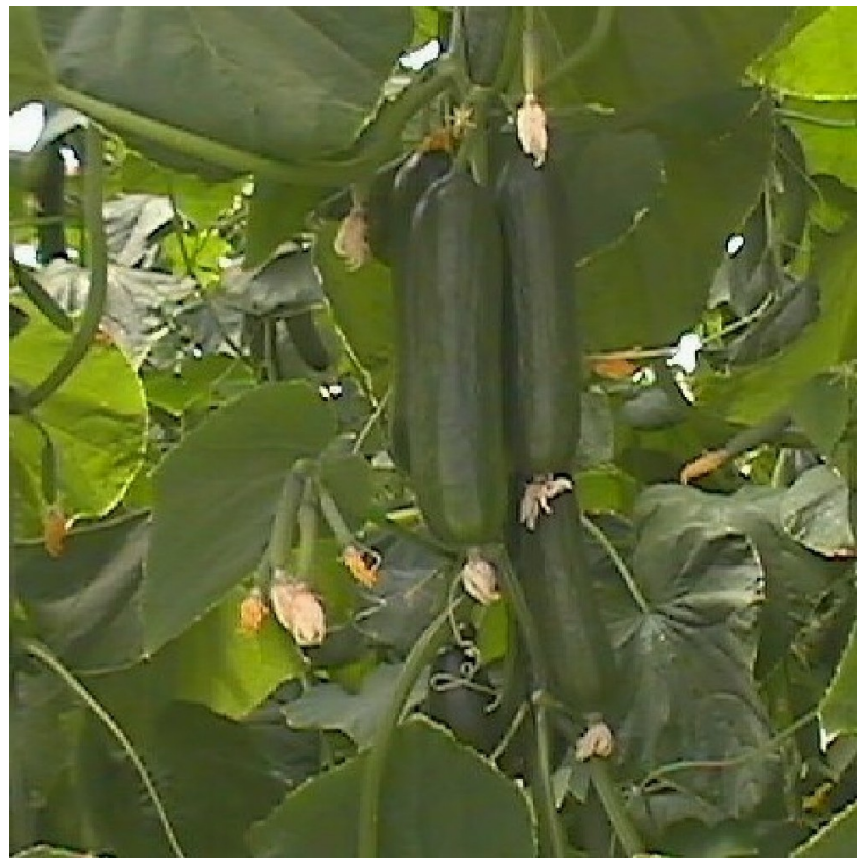

Figure 3. Small Fruit Developing on Pruned Lateral Branch (Cultivar, Meitav). Credits: Daniel J. Cantliffe, UF/IFAS

reduce disease losses. Removal of poor-quality fruit before maturity also helps maintain continuous fruit set. A foot bath containing disinfectant and located at all entryways, as well as removal of all weeds inside and around the greenhouse, will also support sanitation in the greenhouse.

Beit Alpha cucumbers should be harvested at a diameter of 1.5 inches or less. Dutch cultivars are harvested at a diameter of $1.25-1.75$ inches, depending on grade and market. The minimum length at harvest of Dutch-type cucumbers is 11 inches, but Beit Alpha fruit will be approximately half the length of Dutch-type cultivars at an equivalent harvest stage. Unlike Dutch-type cultivars, the fruit should not require plastic wrapping for protection after harvest.

\section{Cultivar Evaluation}

The results of a comparison of six Beit Alpha cucumber cultivars and two Dutch-type cultivars evaluated in two seasons are presented in Table 2. More detailed information can be found in the Proceedings of the Florida State Horticultural Society (Volume 113, 2000), http://www.hos.ufl.edu/protectedag/BeitAlphaCuc.pdf
The cucumbers were grown in an Israeli sawtooth design, passively ventilated greenhouse covered with double-layer polyethylene and located in Gainesville, FL. The sidewalls were $12 \mathrm{ft}$ high, and the peak was $26 \mathrm{ft}$ high. The 3 -ft roof vent and sidewalls were covered with 0.02 -inch screen for insect control.

The Beit Alpha types were Alexander, Dishon, Sarig, and Suzan (available from Hazera Seeds, Inc., 745 Balboa St., Grover Beach, CA 93433) and Ilan and Rambo (available from Zeraim Gedera, P.O. Box 103, Gedera 70750, Israel). The Dutch types were Bologna (available from Rijk Zwaan Export B.V., P.O. Box 40, 2678 ZG DeLier, The Netherlands) and Kalunga (available from Enza Zaden, 407 Front Street, Salinas, CA 93901).

Three transplants at three weeks old were planted in $1 \mathrm{ft} \times 3 \mathrm{ft}$ white polyethylene bags filled with perlite, typical for hydroponic production of Dutch cultivars in Florida. The bags were slit about 1 inch above the ground to allow excess water to leach out and to provide airspace for the roots. The fall 1999 season ran from September 26 to January 26, planting to final harvest. In spring 2000, seeds were planted on February 16, and the final harvest was April 28.

Beit Alpha cultivars produced two to three times as many marketable fruit on a per-season basis, compared to the Dutch cucumber cultivars (Table 2). In Spring, when temperatures increased, the yields of the Beit Alpha cultivars rose -- because of the greater heat tolerance of the Beit Alpha cultivars -- while yields of the Dutch cultivars did not increase.

However, average fruit weight was greater for the Dutch cucumbers because of their greater fruit size at harvest. Beit Alpha cucumbers, while always shorter than Dutch cultivars, vary in length. Sarig is an example of a short Beit Alpha cultivar while Alexander is a longer Beit Alpha type. Average fruit weight and length were greater in Fall than in Spring for both Dutch and Beit Alpha types.

Culls were less than 10 percent of total fruit number for Beit Alpha cultivars, compared to 20 percent of total fruit number for the Dutch types. Uniformity (fruit length, diameter, and shape) was high for all cultivars. All Beit Alpha cultivars had 
smoother skin than the Dutch types, with Ilan having the smoothest skin and Alexander and Rambo having the most wrinkled skin. Both Dutch-type cultivars have reported resistance to powdery mildew. When chemical controls (Dithane or sulfur) were used, only Ilan had more severe symptoms than the Dutch-type cultivars. When no chemical controls were used, all cultivars of both types had more powdery mildew symptoms, but the Beit Alpha cultivar Alexander showed disease levels similar to the more resistant Dutch types.

Dutch cucumbers are shrink-wrapped in plastic after harvest to prevent water loss and damage to the skin. The thicker skins of the Beit Alpha cucumbers, while still thin enough to not require peeling, are better able to survive postharvest handling and marketing. Preliminary local marketing tests showed that the Beit Alpha cucumbers were well received by the Florida consumer.

More recent trials of Beit Alpha-type cucumbers at UF have demonstrated powdery mildew resistant/tolerant lines (Table 3) and new snack-size types (Table 4). The complete reference for this updated research can be found in Acta Horticulturae (Vol. 731,pgs. 251-258) or at the Protected Agriculture Web site (www.hos.ufl.edu/protectedag).

\section{Powdery Mildew Resistance}

Seven Beit Alpha (BA) type cucumber cultivars were compared to six mini-cucumber (MC) type cucumber cultivars in spring 2002. BA types refer to those distributed by Israeli seed companies while MC types are those bred and/or distributed by Dutch and some U.S. seed companies. Several cultivars of both the BA and MC types produced more than 70 fruit per plant while all others in the trial produced less than 65 fruit per plant over 27 harvests. Average fruit weight ranged from 3.8 - 4.9 ounces per fruit.

At the end of the season, plants were rated for coverage with powdery mildew (Sphaerotheca fuliginea) where 1 = no leaves with powdery mildew, and $10=$ all leaves with powdery mildew. Ratings were then converted to percent coverage 10-100 percent. The BA cultivars Meitav and Sarig were rated with greater-than-90-percent powdery mildew coverage. All others -- except the MC cultivar
Sarawat (40 percent) -- had less-than-30-percent powdery mildew coverage.

During this trial, cultivars with high levels of powdery mildew coverage did not have reduced yields compared to cultivars with less powdery mildew coverage. Therefore, powdery mildew may be a visual problem for some BA or MC type cucumbers. It is, however, recommended to consider choosing a cucumber cultivar with powdery mildew tolerance and/or resistance if other crops, such as melons, will be grown in the same greenhouse as the cucumber.

\section{Snack-Size Cucumbers}

In response to consumers increased awareness of the importance of providing fresh vegetables to children and as a convenience for adults, cucumber cultivars are now available in a snack-size version. These new, smaller-size mini-cucumbers are popular in Europe and have potential in the U.S. market.

Three snack-size-type cultivars were compared to four mini-cucumbers cultivars in spring 2004 (Table 4). Plants were grown in a passively ventilated greenhouse structure, similar to that discussed previously, except that the greenhouse used in this trial was covered with a single layer of polyethylene.

The snack-size types were nearly one-third smaller than the traditional, mini-cucumbers types grown. However, overall yields were similar between the snack-size cucumbers and the mini-cucumbers due to the higher number of fruit produced per plant of the snack-size types versus the mini-cucumbers types (nearly 70 compared to an average of 47 , respectively).

These snack-size cucumbers package well in small, take-along clamshells alongside other bite-sized vegetables, such as cherry tomato. 
Table 1. Nutrient solution for greenhouse cucumber production

\begin{tabular}{||r|r||}
\hline \multicolumn{1}{|c|}{ Nutrient } & Parts per million \\
\hline $\begin{array}{l}\mathrm{N} \\
\text { after transplant }\end{array}$ & 100.00 \\
\hline $\begin{array}{l}\mathrm{N} \\
\text { after first harvest }\end{array}$ & 18.00 \\
\hline $\mathrm{P}$ & 50.00 \\
\hline $\mathrm{K}$ & 150.00 \\
\hline $\mathrm{Ca}$ & 135.00 \\
\hline $\mathrm{Mg}$ & 50.00 \\
\hline $\mathrm{S}$ & 65.00 \\
\hline $\mathrm{Fe}$ & 3.00 \\
\hline $\mathrm{Cu}$ & .20 \\
\hline $\mathrm{Mn}$ & .80 \\
\hline $\mathrm{Zn}$ & .30 \\
\hline $\mathrm{B}$ & .70 \\
\hline $\mathrm{Mo}$ & .06 \\
\hline \hline
\end{tabular}




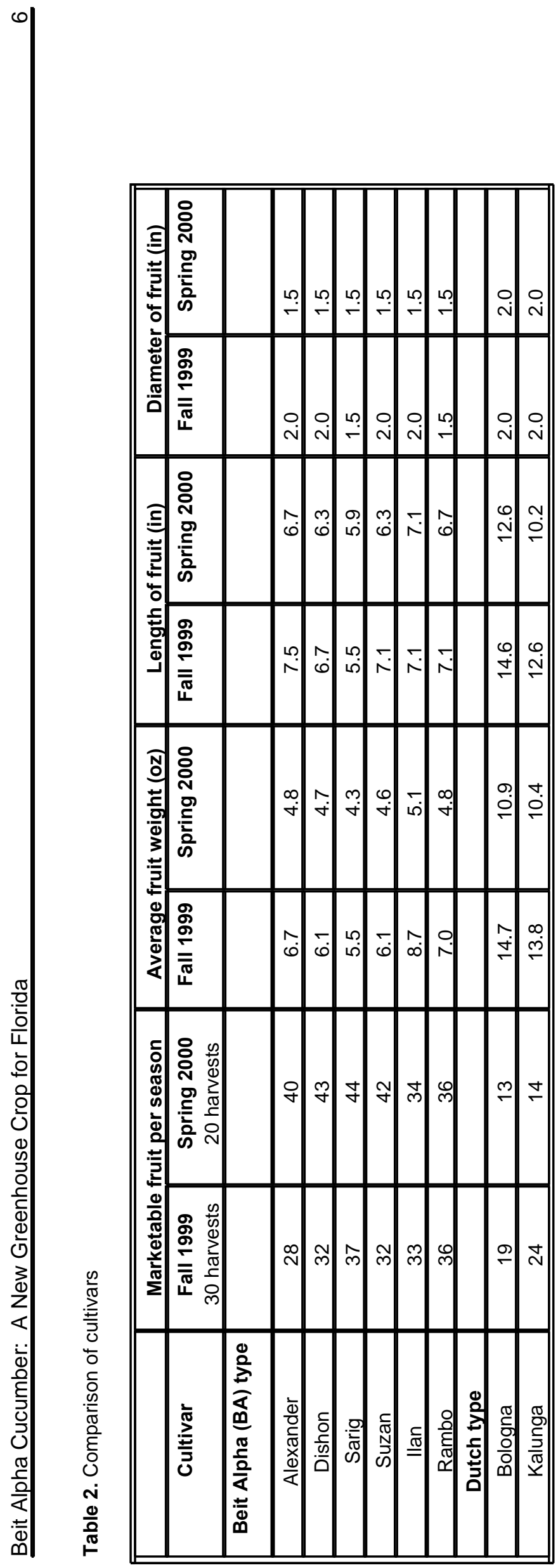


Table 3. Production and Powdery Mildew Rating for 13 Beit Alpha (BA) or Mini-Cucumber (MC) Type Cultivars. Spring 2002. Gainesville, FL.

\begin{tabular}{||l|c|c|c||}
\hline \hline Cultivar & $\begin{array}{c}\text { Average fruit weight } \\
\mathbf{( o z})\end{array}$ & $\begin{array}{c}\text { Marketable fruit no/plant } \\
\mathbf{2 7} \text { harvests) }\end{array}$ & $\begin{array}{c}\text { Marketable weight } \\
\text { (lbs/sq. ft.) }\end{array}$ \\
\hline Mini (MC) types & & 62 & 5.4 \\
\hline Aria & 4.5 & 43 & 4.1 \\
\hline Diva & 4.9 & 63 & 5.7 \\
\hline DeltaStar & 4.8 & 77 & 5.4 \\
\hline Figaro & 3.6 & 73 & 6.0 \\
\hline Manar & 4.3 & 68 & 5.8 \\
\hline Sarawat & 4.4 & 62 & 5.1 \\
\hline Tornac & 4.3 & & 4.1 \\
\hline BA types & & 56 & 5.6 \\
\hline EX1605 & 3.8 & 67 & 5.3 \\
\hline M-733 & 4.4 & 71 & 4.8 \\
\hline Meitav & 3.9 & 64 & 4.9 \\
\hline Sarig & 3.9 & 58 & 4.6 \\
\hline 9976 & 4.4 & 63 & \\
\hline 976 & 3.8 & & \\
\hline \hline
\end{tabular}

Table 4. Production of Snack or Mini-cucumber type cultivars. Spring 2004. Citra, Fla.

\begin{tabular}{||l|c|c|c||}
\hline \hline \multicolumn{1}{|c|}{ Cultivar } & $\begin{array}{c}\text { Average fruit weight } \\
\text { (oz) }\end{array}$ & $\begin{array}{c}\text { Marketable fruit no/plant } \\
\text { (22 harvests) }\end{array}$ & $\begin{array}{c}\text { Marketable weight } \\
\text { (lbs/sq. ft.) }\end{array}$ \\
\hline Snack-size (SS) types & & & 52 \\
\hline Silor & 1.6 & 69 & 3.5 \\
\hline Nun3039 & 1.6 & 68 & 4.3 \\
\hline Nun9747 & 1.7 & & 4.5 \\
\hline Mini (MC) types & & 50 & 3.5 \\
\hline Alamir & 2.3 & 47 & 4.7 \\
\hline Kian & 2.8 & 47 & 4.5 \\
\hline Nun3038 & 2.8 & 43 & 3.7 \\
\hline Tornac & 2.7 & & \\
\hline \hline
\end{tabular}

